Open Access

\title{
Structural equation modeling and confirmatory factor analysis of social media use and education
}

\author{
Shugufta Abrahim, Bilal Ahmed Mir, Hayato Suhara, Fatin Amirah Mohamed and Masahiro Sato*
}

\author{
* Correspondence: masa@eng.u- \\ toyama.ac.jp \\ Graduate School of Science and \\ Engineering for Education, \\ University of Toyama, 3190 Gofuku, \\ Toyama 930-8555, Japan
}

\begin{abstract}
The objective of this study is to design a structural equation model and test confirmatory factor analysis system in order to better explain how students could utilize social networking system (Facebook) for educational purposes. Thus, this paper seeks to examine the attitude, perception and behaviour of Japanese students' towards social-networking sites, and how students from non-English speaking backgrounds (especially Japanese students) at the University of Toyama perceive the use of Facebook for learning English as a foreign language. Our Structural Equation Modelling system based Facebook model outline the relations among different types of independent, dependent variables and constructs. We tested our model using adequate fitting indices like Goodness of Fit Index (GFI), Adjusted Goodness of Fit Index (AGFI), Root Mean Square Error of Approximation (RMSEA), Comparative Fit Index (CFI), Non-Normed Fit Index/Tucker Lewis index (NNFI/TLI) and Incremental Fit Index (IFI). The results of the proposed model confirmed the hypothesized latent structures and theoretical validity of probed factors. Conclusions drawn from this study might be useful to better understand the use of social networking tools in educational context.
\end{abstract}

Keywords: Social media, Facebook, Structural equation modelling, Confirmatory factor analysis, Collaborative learning

\section{Introduction}

The digitization of identity and global networked system, with the ubiquitous computing applications, particularly high quality electronic data creation and maintenance, reveals that common networking concepts are widely found across a range of domains (Hansen, Shneiderman, \& Smith, 2010; Pentland, 2016). Online Social Network (OSN) is a contemporary type of internet phenomenon where everyone and everything is connected. In today's society, social media is a term that everyone knows and all households with youngsters having access to the internet are familiar with multiple social media platforms exist currently. Recent years have witnessed a phenomenal proliferation and widespread use of social media platforms among a large population (Amichai-Hamburger \& Vinitzky, 2010; Chae, 2018; Choi \& Sung, 2018; Rodriguez \& Keane, 2018). It is estimated that more than 3 billion people around the world (around $40 \%$ of the world's population) use online social media.

(c) The Author(s). 2019 Open Access This article is distributed under the terms of the Creative Commons Attribution 4.0 International License (http://creativecommons.org/licenses/by/4.0/), which permits unrestricted use, distribution, and reproduction in any medium, provided you give appropriate credit to the original author(s) and the source, provide a link to the Creative Commons license, and indicate if changes were made. 
(http://www.bbc.com/future/story/20180104-is-social-media-bad-for-you-the-evidenceand-the-unknowns)

(https://wearesocial.com/blog/2018/01/global-digital-report-2018).

Social media platforms offer wealth of unique opportunities to many individuals from all walks of the life in many different ways. These sites are used not only to make friends, send or receive instant messages, but also offer social and participatory virtual platforms that facilitate the users to build and expand social and professional networks with different stakeholders within and beyond geographic territories using a variety of modalities (Greenhow, Robelia, \& Hughes, 2009; Thompson, 2013; Valkenburg, Koutamanis, \& Vossen, 2017).

The overall explosion of social media platforms where multitude of users from around the globe congregate has fundamentally caused a shift in the society on how people communicate and share knowledge with each other, how information flow and diffuses, how people organize social events and make relationships, how businesses compete and operate, how celebrities promote themselves and attract their followers, and how politicians exert considerable influence on voters and contest elections (Fogel \& Nehmad, 2009; Hansen et al., 2010; Junco, 2015; Shen, Brdiczka, \& Liu, 2015). The infiltration and power of new age social networking technology into society is undoubtedly reshaping almost every aspect of life in an unprecedented way, and education sector is no exception (Amichai-Hamburger \& Vinitzky, 2010; Correa, Willard Hinsley, \& Gil se Zuniga, 2010). The unique capabilities and a variety of advantageous features of social networking channels have brought to student community, besides online social entertainment, the utilization of social media platforms for academic and professional activities in a more appealing and modern format (Junco, 2015). The use of social media provide important personal data information regarding social and emotional background, cognitive functioning and psychosocial development scenarios of the youths who spend most of their waking hours staring at the internet-connected systems and devices worldwide (Hayes, van Stolk-Cooke, \& Muench, 2015; Pempek, Yevdokiya, \& Calvert, 2009). Because of exponential growth of huge volumes of user generated online content and the subsequent potentiality to interact, communicate, collaborate, cooperate and share meaningful data in real-time with others conveniently, the social networking platforms are considered to be of profound significance for educational purposes and social media analytics (Hansen et al., 2010; Kuzma \& Wright, 2013; Mazman \& Usluel, 2010; Oh, Ozkaya, \& LaRose, 2014; Pempek et al., 2009; Pentland, 2016; Sanchez, Cortijo, \& Javed, 2014).

Therefore, there has been an increasing interest in the use of social media networks and transmedia skills for educational and learning benefits (Donlan, 2014; Forkosh-Baruch \& Hershkovitz, 2012; Kuzma \& Wright, 2013; Mazman \& Usluel, 2010; Roblyer, McDaniel, Webb, Herman, \& Witty, 2010; Sanchez et al., 2014; Scolari, 2018; Scolari, Masanet, Guerrero-Pico, \& Establés, 2018; Sharma, Joshi, \& Sharma, 2016). Although, social networks have become an integral part of modern society, but it has only recently been explored as a potential tool for educational purposes. A number of recent research studies have shown that social media platforms support educational activities directly or indirectly by making effective interaction and communication, educational information and resource sharing, active participation and cooperative learning (Ajjan \& Hartshorne, 2008; Anderson, Hepworth, Kelly, \& Metcalfe, 2010; Ertmer et al., 2011; Jones, 2015; Larusson \& Alterman, 2009; Mason, 2006; Veletsianos \& Navarrete, 2012). 
Today, there is a tremendous variety of social networking platforms available on the Internet with various technological features, supporting a wide spectrum of interests and practices. Social media platforms such as Facebook, Instagram, Twitter or LinkedIn have an increasing user base (Chawinga \& Zinn, 2016; Cheung, Chiu, \& Lee, 2011; Dzvapatsva, Mitrovic, \& Dietrich, 2014; Gikas \& Grant, 2013). Among Social networking technologies, Facebook remains one of the largest and most popular (especially among student population) social networking sites in existence with over 1.47 billion daily active users and 2.23 billion monthly active users as of 2018 , and $98 \%$ of university or college students are found to have a Facebook profile (Hargittai, 2007; Inma \& Antoni, 2018; Lee, 2011; Madge, Meek, Wellens, \& Hooley, 2009; Moretta \& Buodo, 2019; Wandeep, Vimala, Omer, \& Ajantha, 2019; Zhao, Grasmuck, \& Martin, 2008). The nation with the highest number of Facebook users as of 2018, is India with 270 million users, followed by United States with 207.36 million users. The next is Indonesia with 140 million users, followed by Brazil with 130 million registered users.

http://www.businessofapps.com/data/facebook-statistics/\#1

Facebook usage and engagement is on the rise worldwide. Majority of Facebook users (especially youth) not only frequently log onto this site, but also spend a considerable portion of their daily life on surfing Facebook. Researchers have carried out several studies to investigate the possibility of utilizing Facebook's network for educational uses (Erdem \& Kibar, 2014; Meishar-Tal, Kurtz, \& Pieterse, 2012; Qureshi, Raza, \& Whitty, 2015; Schroeder \& Greenbowe, 2009). While recognizing the importance of the advanced features and capabilities of Facebook for pedagogical purposes, we feel that it is also important to use modeling approach in order to conceptualize the use of Facebook for educational purposes and test hypothetical model for deep social media analysis.

The focus of this research is to examine Japanese students' behaviours towards social networking technology, and how students from non-English speaking backgrounds perceive the use of Facebook for learning English as a foreign language. Although several research studies on social networking exists explaining the motivation underlying users' preferences using social networking system in general and Facebook in particular, but to the best of our knowledge no report has been published using structural equation model for demonstrating the diffusion, benefit and acceptance of Facebook by students from non-English to English as second language learning context.

\section{Facebook literature review}

Facebook is the most predominant and widely visited social media landscape across the globe. Facebook users include individuals from different age groups, education levels, religions, languages, and cultural backgrounds .

(https://newsroom.fb.com/company-info/).

Communicating through Facebook phenomenon has drastically changed the way people maintain their social status and extend social connections with the world around them. Today, Facebook communication platform is very popular among the adolescents and young adults because of several crucial aspects including its user friendly nature, better interface, top notch security of accounts, and it provides instant communication and immediate feedback opportunities (Erdem \& Kibar, 2014; Inma \& Antoni, 2018; Moretta \& Buodo, 2019). In addition, Facebook allow its users to utilize several interesting features in order to perform numerous activities and tasks such as 
creating personal profile for presenting themselves to others, nurturing existing relationships (friends, family members, coworkers, and acquaintances), uploading pictures and videos, posting status updates, expressing personal opinions and views in writing or through live streaming, establishing new relationships, creating Facebook pages/ groups representing public figures, institutions, organizations, businesses, brands or products and other entities (Cheung et al., 2011; Junco, 2015; Thompson \& Lougheed, 2012; Tsay-Vogel, Shanahan, \& Signorielli, 2016; Valkenburg et al., 2017). The purpose of Facebook adoption and usage differs greatly depending on users' interests, priorities, affiliations, attitudes and perceptions (Brailovskaia \& Bierhoff, 2016; Hayes et al., 2015; Junco, 2015; Kuzma \& Wright, 2013; Toker \& Baturay, 2019; Wandeep et al., 2019).

Given the widespread acceptance and growing popularity of Facebook based social media among the young population, it is necessary to understand how Facebook usage influences on users' social routine, emotional connection, social integration and educational activities. A plethora of research studies have been conducted on Facebook from different facets. Several studies have demonstrated the influence of prolonged use of Facebook on the psychological characteristics (attitudes and behaviors) of users (Amichai-Hamburger \& Vinitzky, 2010; Correa et al., 2010; Dickie \& Meier, 2015; Hayes et al., 2015; Lönnqvist \& große Deters, 2016; Ross et al., 2009; Ryan \& Xenos, 2011; Sagioglou \& Greitemeyer, 2014; Shen et al., 2015; Wilson, Fornasier, \& White, 2010). Some other existing studies pinpoint the effect of Facebook media interaction between users (Brailovskaia \& Bierhoff, 2016; Mendes, Furtado, Militao, \& de Castro, 2015), and several other studies have been carried out to investigate the privacy, trust and security concerns on Facebook (Junior, Xavier, \& Prates, 2014; Külcü \& Henkoğlu, 2014; Saeri, Ogilvie, La Macchia, Smith, \& Louis, 2014; Tsay-Vogel et al., 2016).

Until now, researchers and social media specialists virtually do not have reached a unanimous agreement on whether use of Facebook elicit positive effects, negative effects or both on the life style and well-being of its users, especially youth, perhaps because Facebook usage promote both positive and negative feelings. The overall outcome depends on numerous factors and parameters, which are directly or indirectly related to attitudinal, behavioral and innate characteristics of users or series of Facebook specific features, among others (Debatin, Lovejoy, Horn, \& Hughes, 2009; Fogel \& Nehmad, 2009; Pempek et al., 2009; Urista, Dong, \& Day, 2009). There seems to be a consensus among networking technology researchers on the idea that Facebook user experience and boost adequate positive emotions (Kross et al., 2013; Oh et al., 2014).

Even though, Facebook platform offer tremendous educational potentials, Facebook has been extensively utilized for social activities (interaction with each other based on shared interests, backgrounds or characteristics) rather than using it as a substitute for educational purposes. However, the growing popularity of Facebook based social networking among college/university students across the globe has led social media communication researchers and educators to investigate and identify several determinants that may motivate and attract the students to embrace Facebook in educational contexts or to highlight its potential influences on students' non-academic and academic outcomes (Dabner, 2012; Toker \& Baturay, 2019).

Recently, there has been a tremendous increase in the number of published papers emphasizing the potential benefits of implementing Facebook in the educational and learning domain. The rapidly growing body of literature suggest that today's student 
community perceive Facebook as a suitable environment for educational sectors and the reported works have yielded mixed results. For example Ellison, Steinfield, and Lampe (2007), reported that Facebook play an important role in the initiation of constructive relationships among college students and progression or maintenance of social capital. According to Madge et al. (2009), Facebook can be used for informal learning because it acts as a social glue that keeps students connected with people who they do not meet or see often due to distance or other reasons, provide them both the opportunities and capabilities to get to know other students and potentially support them transition into college or university life. Similarly, Prescott, Wilson, and Becket (2013) demonstrated that university students use Facebook for informal education especially for peer to peer support purposes. Thompson and Lougheed (2012) found $80.24 \%$ of university students believe that Facebook has a significant and positive impact on campus engagement for cross-cultural networking activities and interactions. Another study carried out by Junco (2015), explained the role of Facebook use and multitasking by comparing academic success of different levels of American undergraduate students based on their cumulative grade point average scores (GPA). Studies have also indicated that the familiarity of educators with Facebook and its main features open possibilities to create virtual study group for educational activities (Charlton, Magoulas, \& Laurillard, 2012). Teachers and students connection via Facebook system can be potentially useful as an available means of communication between teachers and students. According to Mazer, Murphy, and Simonds (2007), professors who use Facebook profiles often post questions on the wall of their Facebook pages and participate in online discussions with students.

Researchers such as Bowers-Campbell (2008) described that educators can utilize Facebook to discuss students concerns and problems related to their assignments, examinations and other educational issues of shy or quiet students. Nonetheless, various studies indicated that the benefit of using Facebook based platform for teaching and learning activities extend beyond the social and cultural aspects (Erdem \& Kibar, 2014; Toker \& Baturay, 2019; Towner \& Munoz, 2011). This view was further advocated by the results obtained by Towner and Munoz (2011) who observed that about half of the participants in that study responded that they use their Facebook educational groups not only for communicating and discussing social events, but also for formal learning purposes including sharing study material, communicating with concerned teachers about courses, exams and homework assignments. Similar results were published by Mao (2014) using an explanatory sequential mixed methods design approach for high school students. Yunus and Salehi (2012) investigated the perception of university students towards Facebook groups for improving their writing skills. Hamid, Waycott, Kurnia, and Chang (2015) found similar results for student-student and student-lecturer interactions among Malaysian and Australian universities participants. Several other studies reported the similar results for American students (Gikas \& Grant, 2013), for Serbian students (Milosevic, Zivkovic, Arsic, \& Manasijevic, 2015) and for Egyptian students (Sobaih, Moustafa, Ghandforoush, \& Khan, 2016), respectively. The overall social media research suggests that the encouragement, motivation and satisfaction of students to utilize Facebook for purposes other than just social and networking activities (both formal and informal learning), has increased over the past few years (Aydin, 2014; Erdem \& Kibar, 2014). 
It is well established that the academic performance and dedication of students for the effective learning outcome is largely dependent on the degree of students' engagement in appropriate range of educational activities (attending lectures and performing tasks) in academic settings. It is very important and highly essential to adopt studentcentered innovative teaching and learning methodologies or to provide new technological solutions that facilitate active learning environments for enhancing students' attention, focus, engagement, and active learning in educational domains. Social networking systems, (especially Facebook), offer multiple student centric features that are more alluring than conventional learning environments. Since student community explore Facebook in school, college and university campuses on their personal smartphones and other personal electronic gadgets, it is much easily accessible to them. Using the numerous advantageous features of Facebook educators can share many educational resources by simply posting different contents, assignments, learning modules, lesson plans, contemporary tests, training experiments and surveys on the virtual study group pages that students require to process as a task in the lectures or interactive teaching/learning tasks that can be of great help to the conventional way of teaching and learning strategies (Kirschner \& Karpinski, 2010; Thompson, 2013). Although, supportive student-teacher relationships are important to boost achievement but teacher should undeniably remain highly cautious in using or posting content on a Facebook outlet, because poor communication can damage or ruin their reputation, credibility and integrity (Mazer et al., 2007).

From an educational perspective, Facebook offer new avenues for the future research and development in the areas of social media and educational technology. For example, the use of Facebook can be initiated by the institutions/universities to probe the suitability of this social networking site as teaching/learning tool and to identify its educational advantages that facilitate relatively a large population of young people to improve significantly the student's engagement in the learning process. Considering previous literature findings, we propose a structural model equation model and test confirmatory factor analysis system to determine the student's perceptions, attitudes, behaviours and experiences towards Facebook educational usage.

\section{Research model and hypothesis}

Throughout history, researchers have tried to understand and predict the concept of technological innovation paradigms. Many theories have been developed over time that provide with explanations of emergence of new technological systems in terms of diffusion, acceptance and benefit and also pointed out why some users become addicted to use certain technologies or become dependent upon them (Ajjan \& Hartshorne, 2008; Ajzen, 1991; Carlile, Jordan, \& Stack, 2004; Davis, 1989; Fishbein \& Ajzen, 1975; Rogers, 2003; Venkatesh \& Davis, 2000; Venkatesh, Morris, Davis, \& Davis, 2003). Dozens of models have been constructed based on these theories, which is probably the easiest way of defining and analyzing the problems or situations so that the underlying issues can be more easily understood and addressed (Corrocher, 2011; Lai \& Chen, 2011; Mazman \& Usluel, 2010; Moore \& Benbasat, 1991; Sanchez et al., 2014). In this study, we constructed a structural model by considering the technological as well as social aspects of social networking system to examine the student's educational activities. Our Facebook model exclusively consist of three latent variable indicators (benefit of 
Facebook, purpose of Facebook and social media usage of Facebook) and 14 observable variables (Fig. 1). Benefit as a latent variable was described by five observed variables; perceived usefulness, perceived ease of use, social influence, collaborative platform and perceived enjoyment. The items designed for the Facebook usage and to asses benefit scale generated after a comprehensive literature survey on existing benefit, diffusion, acceptance and usage models and theories. Hence, related or similar themes were classified under some tentative categories (Fig. 1a-c).

\section{Benefit of social networking system (Facebook)}

A conceptual framework for understanding the acceptance, diffusion, benefit, and innovative use of social media technology for educational purposes (content development and virtual classroom use) must delineate characteristics of participating individuals/groups, media features, relations of media and individual social networks. The model presented in this work demonstrates the benefit of social networking system, particularly Facebook (Fig. 1a). We depicted Facebook benefit as a latent variable and described nominal variable indicators including, perceived usefulness (fundamental determinant of user acceptance), perceived ease of use (determinant of user behavior), social influence (thoughts actions, reactions of users influenced by other individuals or groups), perceived enjoyment (intention to use technology for fun) and collaborative platform (can be used as collaboration).

\section{Perceived usefulness and perceived ease of use}

Perceived usefulness is an important determinant of information system that supports decision-making/problem-solving activities. The significance of perceived usefulness has been extensively acknowledged in E-banking sector (Eriksson, Kerem, \& Nilsson, 2005; Guriting \& Ndubisi, 2006; Liao \& Cheung, 2002). According to these studies, usefulness is the subjective probability that using modern technology is a great way to complete or improve the outcomes for a given task. In 1985, Davis proposed the actual Technology Acceptance Model (TAM) as an extension of the Theory of Reasoned

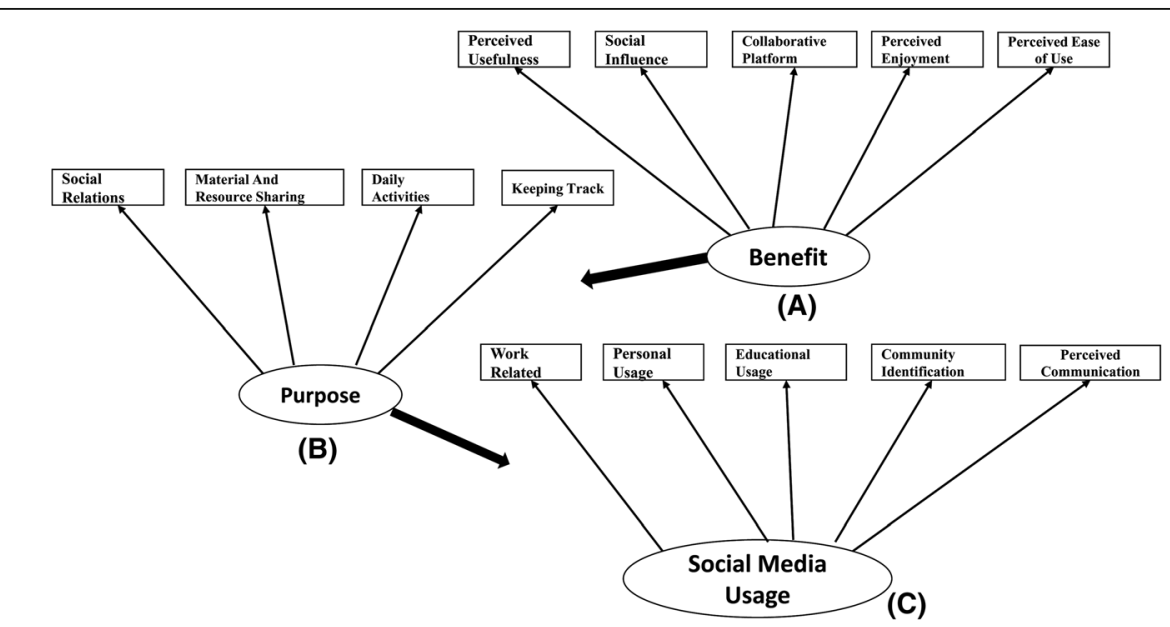

Fig. 1 The research model consist of three latent variable indicators; (a) benefit of Facebook, (b) purpose of Facebook and (c) social media usage 
Action (Davis, 1989; Fishbein \& Ajzen, 1975). TAM is one of the most popular prediction-oriented research models dedicated to predict the primary motivational factors for the use and acceptance of new technologies and systems. According to Davis (1993), perceived usefulness can be defined as "the degree to which an individual believes that using a new technology or an information system would enhance his or her productivity. Perceived ease of use, in contrast, can be defined as "the degree to which a person believes that using a particular technologies and systems would be from mental or physical exertions (Davis, 1989).

Facebook Platform provides a set of tools, features and opportunities, which enable users to enjoy several online activities. Therefore, we chose Facebook for this research investigation. In this case, Facebook perceived usefulness is defined as "the degree of psychological immediacy and belief formation that using Facebook networking technology enhances performances of its users." Facebook perceived ease of use is referred as the degree to which an individual believes that using Facebook would be free of mental or physical efforts.

Hypothesis 1 (H1): Perceived Usefulness will have a significant influence on user Facebook acceptance and benefit modes

Hypothesis 2 (H2): Perceived Ease of Use will have a remarkable effect on Facebook benefit modes.

\section{Social influence}

Social influence is a broad term that refers to multiple phenomena. In the past decade, various measures and definitions of social influence have been introduced in the prominent area of technology innovation and benefit. Social influence best describes "the extent to which individuals perceive that important or significant others believe they should embrace new technology and systems" (Venkatesh et al., 2003). Triandis (1980) refereed social influence or social factors as "the individual's internalization of the reference groups subjective culture, and specific interpersonal agreements that the individual has made with others, in specific social situations".

In this study, the concept of Social Influence is described as the degree to which a Facebook user perceives the importance of his/her significant others will response upon performing specific behaviors.

Hypothesis 3 (H3): Social Influence will have a significant relationship with Facebook benefit.

\section{Perceived enjoyment}

Self-service technologies (SST) have become omnipresent in modern society. Spectrum of self-service technologies have successfully launched and promoted in order to replace conventional services. The benefits of such technologies has well investigated in different contexts. Davis, Bagozzi, and Warshaw (1992) described the term perceived enjoyment in terms of technology benefits and usage as "the level whereby any task is deemed to be enjoyable regardless of other parameters like performance outcomes as a result of the system or service use." Eighmey and McCord (1998) expressed that 
perceived enjoyment is a key influencing factor of intention to use internet and have a positive impact on the users' choices of web browsing and application usage. Recently, Curran and Meuter (2007) reported that the users' behavioral intention toward using social media is generally examined by the degree of enjoyment they experience which reflects that the benefit of self-service technology can certainly be impacted by the perceived enjoyment. In this study, the perceived enjoyment is described as the extent to which a Facebook user experience high level of enjoyment and positive interaction with their peers.

Hypothesis 4 (H4): Perceived enjoyment will have a significant effect on Facebook benefit and interaction modes.

\section{Collaborative platform}

Collaborative platforms are procedures, behaviors, and discussions or consultation that relate to the collaboration between individuals, groups or systems. Social networking tools such as Facebook can be utilized to create models for collaborative platform to facilitate cross-program collaboration or to create comfortable and familiar social settings among different individuals or other entities. Maloney (2007), demonstrated that the conversational, collaborative and communal characteristics of Social Networks augment the awareness of the process of learning.

Hypothesis 5 (H5): Collaborative platform will have a tremendous impact on benefit of Facebook

\section{Purposes of Facebook usage}

Facebook has widely been used for so many diverse purposes, including contacting friends, maintaining social relationships, following updates about friends, school or class, visiting other's profiles to obtain information about them, communicating with teachers, requesting information, uploading, tagging and sharing personal information or multimedia content and creating Pages or groups or joining different groups of common interests or pursuits (Ellison et al., 2007; Ito et al., 2008; Livingstone, 2009; Patterson, 2012; Stutzman, 2006). Depending on the purposes, the content user's put on the social media differs in the formality, considered audience, and desired consequences (Fig. 1b). The main purpose of this study is to design a structural equation model and apply confirmatory factor analysis system in order to investigate diffusion, benefit and acceptance of Facebook by undergraduate, graduate and research students at the University of Toyama. The overall results generated based on users' social relations, their daily activities, purposes of Facebook usage and Facebook educational usage. In addition, we analysed attitude, perception and behaviour of Japanese students' toward Facebook for educational usage, and determined how students from non-English speaking backgrounds (especially Japanese students) at the University of Toyama perceive the use of Facebook for learning English as a foreign language. Finally, we designed and used the model, after studying a compressive literature based on benefit, diffusion, acceptance and usage theories.

Thereafter, we analysed various factors affecting the relationship between the benefit processes and social characteristics users portrayed on Facebook for different activities. 
The final data analysed and fitted using structural equation modelling validates that the model designed for evaluating the effects of multiple variables on benefit of Facebook are perfectly fitted.

\section{Social relations}

One main facet of social networking service (especially Facebook) is its emphasis on creating and maintaining relationships, which include meeting new people and making friends, nurturing and maintaining good relations with existing ones. The frequent usage and popularity of Facebook is well documented in recent reports (Mazman \& Usluel, 2010).

Hypothesis 6 (H6): Social relations will have a great impact on purposes of Facebook usage.

\section{Resource/material sharing}

Facebook has been a boon for most social media users, permitting even the most nontech savvy person a possibility to connect with friends, exchange ideas and information, and predominantly have online existence. Facebook allow anyone to post online or share their relevant resources, materials like links or photos, projects or other documents. The content management capabilities of Facebook including uploading of images, audio or video clips can be very beneficial for various purposes.

In this study, the purpose of Facebook use for material/resource sharing consists of various tasks including, exchanging videos and audios, multimedia resources, projects of other document files etc.

Hypothesis 7 (H7): Resource and material sharing will have a great impact on the purpose of Facebook use.

\section{Daily activity}

Facebook dominate daily activity landscape, as notable majorities of youth use Facebook site worldwide (Cheung et al., 2011). The daily activities of the people who use Facebook with varying degrees of frequency include wasting time on Facebook, keeping up to date with what is happening around one's different level of social connections, having fun, playing games, monitoring social feedback on their status or joining other groups.

Hypothesis 8 (H8): Daily activities will have a great impact on purposes of Facebook use.

\section{Keeping track}

Keeping track of trends on the Facebook platform is now very popular (Sanchez et al., 2014). With the help of social Facebook features, users can easily keep track of what is happening around them and about the continued progress of other people.

Hypothesis 9 (H9): Keeping track will have a great impact on purposes of Facebook usage. 


\section{Social media usage}

Unlike conventional media, social media technology is a disruptive mode of information communication among individuals, networks and devices as it enables multiple users to participate in virtual-reality and have their input in the discussion, no matter the conversation. The rapid development and popularization of information technology facilitates access to social networking system to large numbers of student population. Among various social networking sites, Facebook is very popular among students. Owing to its various features and utilities, it is widely considered as a useful tool for personal, work or education related online activities. There is a growing interest in social media technology research to analyze functionality and potential of social media tools in educational contexts. Some studies have examined that many social networking sites especially Facebook directly or indirectly facilitate informal learning process because of their engaging role in users' daily routines and activities. It is believed that social networking system can support multiple personal, work related, and educational activities (Fig. 1c). According to (Lee \& McLoughlin, 2008), social networking sites acts as useful pedagogical tools because student users can effectively use many features of these sites for connections, collaboration, content creation sharing, information aggregation and knowledge modification. Framing a comprehensive Facebook policy that includes guidelines, recommendations, best practices and training tips for educational usage is therefore very essential.

\section{Personal usage}

Facebook is a specific type of social networking that allows users to connect with others and create a page, group or community. It is more about establishing relationships, exchanging information, sharing ideas, discussing topics of profound importance, collaborating with other on numerous projects than just sending messages to contacts or posting post status updates in the feeds (Mazman \& Usluel, 2010; Roblyer et al., 2010; Sanchez et al., 2014; Sharma et al., 2016). Users can both utilize Facebook platform to nurture their personal friendship, to keep in touch with personal family and close relatives who live far away, to post personal updates or engage with fans and followers. Facebook for personal and educational usage consist of activities such as online conversation among students and their parents and friends.

Hypothesis 10 (H10): personal usage will have a great impact on social media usage of Facebook.

\section{Educational usage}

From educational point of view, Facebook is appraised as an acceptable social media platform for education because of its structure and controlled utilities. Many researchers believe that Facebook is a useful tool to develop confidence to enhance the communication skills among students/learners in various educational settings (Mazman \& Usluel, 2010). Facebook based collaboration among various individuals for educational purposes consist of multiple activities. For example, joining various groups related to users institutions academic or extracurricular activities, peer to peer sharing of ideas, homework, assignments or project reports, or joining virtual classes. 
Hypothesis 11 (H11): educational usage will have a great impact on social media usage of Facebook.

\section{Work related usage}

Now a day, Facebook is increasingly utilized by employees in various organizations for sending messages for personal and professional purposes during working time. There are several benefits of using social media at workplace, such as, creation and strengthening of ties with other organizations, collecting and analyzing information about market and competitors, free calling and chatting with a coworker about any subject, actively sharing, projects, materials, resources, work progress reports or supporting coworkers by using online and offline web functions (Donlan, 2014; Forkosh-Baruch \& Hershkovitz, 2012; Kuzma \& Wright, 2013; Sanchez et al., 2014; Sharma et al., 2016).

Hypothesis 12 (H12): Work related usage would have a great impact on social media usage of Facebook.

\section{Community identification}

Social identity is an individual's belief about himself or herself, which is generally characterized by distinguishing factors: the feeling of reciprocal interaction, sympathy and responsibility among members of a group, which promote a sense of belonging within the community (solidarity to the group), specific conformity to ingroup norms and outgroup derogation or discrimination against outgroups (Riedlinger et al., 2004). In general, personal identity deals with questions about ourselves. In contrast, social identity designates that a particular member belongs to a particular society or group (Hogg, 2012). The individual's identification with a social group has a positive impact on his/ her self-image (Apaolaza et al., 2013; Dholakia et al., 2004; Valkenburg et al., 2017). In Facebook usage context, social identity can be outlined as the users' identification within an online social network and virtual community.

Hypothesis 13 (H13): Community identity will have a great impact on social media usage.

\section{Perceived communication}

The youths of today feeling more relaxed and comfortable expressing themselves over text or social networking system than communicating via traditional face-to-face or telephonic conversation. They spend a lot of time on social media channels in order to emote and discuss about their real world real-life interactions, relationships and experiences. With proper framework and guidance on the utility of social media especially Facebook, it can be easy to create and promote online connections between teachers and students within educational settings. This strategy can help to improve overall communication within students and teachers communities, which will ultimately lead to better educational discussions beyond the classroom (Christofides et al., 2009; Mazer et al., 2007; Ross et al., 2009). 
Hypothesis 14 (H14): Communication will have a great impact on social media usage of Facebook.

To construct structural equation model for Facebook usage, we first analyzed and determined various factors and variables that influence potential Facebook benefit processes and users sentiments. It was assumed, while constructing the structural equation Facebook model, that Facebook benefits are directly or indirectly associated with purposes of Facebook usage. This lead to the logically derived explanation or hypothesis that when different individuals' choose to get benefit from new instructional materials or technologies, they use the beneficial systems for different purposes in their everyday lives, which give individuals the opportunities to make better choices. For instance, if individuals perceive some media is effective, useful or easy to use they tend to get benefit from it for accomplishing their desired tasks. Likewise, members of a particular community may get benefit from a material or product because of the virtual peer influence on user's behavior from a community or group that they interact or communicate with socially or professionally, the outcome of which can be a convoluted network of identification with multiple communities from random walks.

Hypothesis 15 (H15): Facebook benefit will have a significant and positive relationship with purposes of Facebook usage.

Considering that the members of a particular community or region succeed in achieving essential learning opportunities when they use social networking technology (Facebook), both media characteristics and socio cultural dimensions of individuals with social media usage affect the entire educational attainment context. Therefore, it is indicated that together with Facebook benefits, motives of Facebook members are in sustained inundation with the academic related usage of Facebook.

Hypothesis 16 (H16): Facebook benefit mediated by the purposes of Facebook usage will have a significant and positive relationship with social media usage of Facebook.

\section{Method}

\section{Instrument}

The process of data collection took place in the University of Toyama and most of the study subjects were undergraduate, postgraduate students and researchers. Questionnaires that were the main tool of data collection were distributed manually and through online to estimate the influence of the social media factors, to propose various research hypotheses, to test the hypotheses by constructing structural equation model and to predict the outcome using test confirmatory factor. A structured questionnaire was distributed to a large number of male and female students. However, only 385 students responded and returned the fully answered questionnaire which were used for further analysis. This number is seen acceptable as it is reported that such studies requires at least 150 respondents to actively participate. According to Hair et al. (2010), for structural equation modeling (SEM) technique, 150 is acceptable parameter for measuring less than seven constructs and modest communalities. 
In addition, we collected the data by means of an online survey, which was developed by the researchers. The survey consisted of three sections. In the first section, demographic characteristics of Facebook users were collected through four questions. Members' frequency of Facebook usage, length of time spent in Facebook, and memberships to Facebook groups were collected within this section.

The second section was composed of a 5-point Likert scale with 5 questions aimed at gathering the members' purposes of Facebook Usage, 5 questions aimed at gathering about the member's benefit of Facebook and 5 questions for usage of Facebook. We tested validity and reliability of the scales. For validity, expert opinion was attained to see if the questions were appropriate in measuring the intended research questions and if the statements were understandable. Based on the feedback received from the experts, the scale was modified. Then, confirmatory and explanatory analyses were conducted to identify the relations between factors and factor loads. For the reliability analysis, Cronbach's alpha values were calculated for each of the scales and their subfactors. While developing the Facebook benefit scale, diffusion, acceptance, usage and purpose theories and models were reviewed to expand the coverage of the scale items.

The data obtained for the explanatory factor analysis revealed that the factor loads of items varied from 0.530 to 0.907 . The Cronbach's alpha reliability coefficient of the scale was found to be 0.883 . The Cronbach's alpha values for each of the factors, factor loadings of the items and goodness of fit indexes of confirmatory factor analyze results are presented in the tables.

\section{Participants and data collection}

Although a large proportion of surveyors were accessed, the study group consisted of 385 Facebook users who responded to the manual and online survey. We had 7 variables with missing values less than $5 \%$, which we replaced with the median for ordinal scale and mean for continues scale. We also deleted four rows as they had more than $20 \%$ missing values. The web address of the survey was spread out in Facebook to the University of Toyama students and people who took the survey forwarded the survey's link to their friends in University of Toyama voluntarily. Also, with the aim of accessing an extensive crowded people survey's link was written on the various Facebook groups' wall that belongs to the University of Toyama students. The survey was kept open for these participants on the web for 4 weeks. Table 1 summarizes the demographic profile of the participants including their gender, educational level language used, in addition to the descriptive statistics of their frequency of Facebook usage and length of stay in Facebook. As shown in the Table 1, percentage of males were $70.2 \%$ and percentage of females were $29.8 \%$. All of the respondents were college students among which $23 \%$ of the participants used Facebook 1-3 times a day, and only 18\% don't use daily. $36.9 \%$ of the students were using Facebook from more than 4 years and $25 \%$ of the respondents use Facebook less than a year.

\section{Results}

\section{Testing the structural model}

In this study, we used structural equation modelling (SEM) and confirmatory factor analysis (CFA) tools for data analysis and testing relationships between variables. We 
Table 1 Demographic profiles and descriptive statistics of the surveyors

\begin{tabular}{|c|c|c|c|c|c|}
\hline Item & & Frequency Percentage & \multicolumn{2}{|c|}{ Mean } & Std. Error of Mean \\
\hline \multirow{2}{*}{ Gender } & Male & 268 & 70.2 & \multirow{2}{*}{1.30} & \\
\hline & Female & 114 & 29.8 & & 0.023 \\
\hline \multirow{3}{*}{ Degree Type } & Undergrade & 116 & 30.4 & \multirow{3}{*}{1.95} & \multirow{3}{*}{0.038} \\
\hline & Master & 169 & 44.2 & & \\
\hline & $\mathrm{PhD}$ & 97 & 25.4 & & \\
\hline \multirow[t]{3}{*}{ Language used } & Native & 131 & 34.3 & \multirow{3}{*}{2.19} & \multirow{3}{*}{0.047} \\
\hline & English & 49 & 12.8 & & \\
\hline & Both & 202 & 52.9 & & \\
\hline \multirow{5}{*}{$\begin{array}{c}\text { Frequency of logging } \\
\text { into FB }\end{array}$} & daily(1-3)times & 88 & 23.0 & \multirow{5}{*}{3.22} & \multirow{5}{*}{0.076} \\
\hline & daily(4-6)times & 48 & 12.6 & & \\
\hline & daily(7-9)times & 11 & 2.9 & & \\
\hline & $\begin{array}{l}\text { daily whenever get } \\
\text { time }\end{array}$ & 163 & 42.7 & & \\
\hline & not daily & 72 & 18.8 & & \\
\hline \multirow[t]{4}{*}{ Length of using FB } & $(0-1)$ years & 97 & 25.4 & \multirow{4}{*}{2.64} & \multirow{4}{*}{0.062} \\
\hline & (1-2)years & 86 & 22.5 & & \\
\hline & $(3-4)$ years & 58 & 15.2 & & \\
\hline & more than 4 years & 141 & 36.9 & & \\
\hline
\end{tabular}

performed SEM and CFA using SPSS (a software for statistical data analysis) and AMOS (a software that can be used to perform structural equation modeling). In brief, structural equation modeling is a family of multivariate statistical analysis methods used to model a network of complex structural relationships between one or more measured variables and latent constructs. Confirmatory factor analysis (CFA) method is used to verify the factor structure of a set of observed variables (Joseph, Marko, Torsten, \& Christian, 2012). The proposed equation model that explain educational usage of Facebook was constructed using three latent variables, namely, Facebook benefit, users' purposes and social media usage of Facebook were examined. Facebook benefit ("benefit") was an Exogenous (independent) latent variable and "B_Usef" (perceived usefulness), "B_Euse" (perceived ease of use), "B_SocInf" (social influence) "B_Enj" (perceived enjoyment) and "B_ColPlm" (Collaborative platform) were observed variables to be accepted as significant anticipator of benefit. Users' purposes ("purpose") was Endogenous (dependent) latent variable and "P_DailyAct" (Daily activities), "P_MnRS" (resource/material sharing) and "P_SoReln" (Social Relations) and "P_ KpTrk" (Keeping Track) were observed variables accepted as significant anticipator of purpose. Social media usage of Facebook ("Usage") was another Endogenous (dependent) latent variable and "U_WrkR" (work related), "U_PerUsg" (personal usage), "U_EduUsg" (educational usage), "U_Iden" (perceived Identification) and "U_Com" (Communication) were observed variables, being accepted as significant anticipator of educational usage. We got three factors in the total variance experienced and that was the exact number of factors we wanted and the total variance experienced by the model was $71 \%$ and that is reasonable percentage of variance (Table 2).

The $\mathrm{c}^{2}$ /df (chi-square /degree of freedom), Goodness of Fit Index (GFI), Adjusted Goodness of Fit Index (AGFI), Root Mean Square Error of Approximation (RMSEA), Comparative Fit Index (CFI), Non-Normed Fit Index/Tucker Lewis index (NNFI/TLI) and Incremental Fit Index (IFI) were examined to check the felicitousness of the 
Table 2 Total variance experienced

\begin{tabular}{|c|c|c|c|c|c|c|c|}
\hline \multirow[b]{2}{*}{ Factor } & \multicolumn{3}{|c|}{ Initial Eigenvalues } & \multicolumn{3}{|c|}{ Extraction Sums of Squared Loadings } & \multirow{2}{*}{$\begin{array}{c}\text { Rotation Sums } \\
\text { of Squared } \\
\text { Loadings } \\
\text { Total }\end{array}$} \\
\hline & Total & $\%$ of Variance & Cumulative \% & Total & $\%$ of Variance & Cumulative \% & \\
\hline 1 & 5.592 & 39.946 & 39.946 & 5.296 & 37.831 & 37.831 & 4.065 \\
\hline 2 & 3.138 & 22.415 & 62.361 & 2.871 & 20.508 & 58.339 & 4.183 \\
\hline 3 & 2.093 & 14.953 & 77.313 & 1.803 & 12.882 & 71.221 & 3.563 \\
\hline 4 & 0.508 & 3.629 & 80.942 & & & & \\
\hline 5 & 0.429 & 3.067 & 84.009 & & & & \\
\hline 6 & 0.369 & 2.633 & 86.642 & & & & \\
\hline 7 & 0.316 & 2.258 & 88.901 & & & & \\
\hline 8 & 0.292 & 2.086 & 90.987 & & & & \\
\hline 9 & 0.278 & 1.986 & 92.973 & & & & \\
\hline 10 & 0.236 & 1.684 & 94.657 & & & & \\
\hline 11 & 0.219 & 1.567 & 96.224 & & & & \\
\hline 12 & 0.206 & 1.468 & 97.692 & & & & \\
\hline 13 & 0.172 & 1.225 & 98.917 & & & & \\
\hline 14 & 0.152 & 1.083 & 100.000 & & & & \\
\hline
\end{tabular}

solution and goodness-of-fit of the model (Table 3). As shown in Table 3, all the indices exceeded their commonly accepted levels, demonstrating that the measurement model exhibited a good fit. Standardized and unstandardized path coefficients of structural model are shown in Figs. 2 and 3, respectively. We observed the pattern matrix (Additional file 1: Tables S1-S7) of all the three factors and the coefficients between benefit and its observed variables were found to be significant $(p<.005$ or $\mathrm{t}>1.96)$. The overall results showed that the five observed variables, which are perceived usefulness, perceived ease of use, social influence, perceived enjoyment and collaborative platform have appreciably positive effect on Benefit $(\beta=0.87, \beta=0.87, \beta=0.90, \beta=$ $0.85, \beta=0.80)$. (H1, H2, H3, H4, H5 supported).

While checking the coefficients between purposes of Facebook usage and its observed variables, we found it to be significant $(p<.005$ or $t>1.96)$. The results obtained for four observed variables, namely social relations, material and resource sharing, keeping track and daily activity showed an appreciably positive impact on purpose $(\beta=0.79$, $\beta=0.76, \beta=0.90, \beta=0.86$ ). (H6, H7, H8 and H9 supported). The results for coefficients between usage of Facebook and its observed variables also showed good significance $(p<.005$ or $\mathrm{t}>1.96)$. the overall data showed that that the five observed variables namely; communication, perceived identification and work related, personal usage and educational usage have also appreciably positive effect on Facebook usage $(\beta=0.76, \beta=$ $0.88, \beta=0.86, \beta=0.89, \beta=0.77)$. ( $\mathrm{H} 9, \mathrm{H} 10, \mathrm{H} 11, \mathrm{H} 12$ and $\mathrm{H} 13$ are supported).

In addition, we also tried to analyze the effect of Facebook benefit on Facebook purpose, and we obtained standardized path coefficient value (0.24) and the t-value (4.29). Thus, we assume that Facebook benefit has a positive effect on users' purposes $(p<.005)$ (H14 supported). Besides this, we found that Facebook benefit has approximately $74 \%\left(R^{2}\right)$ of the variance of purposes of Facebook usage. We also tried to examine the effect of users' purposes on the usage of Facebook, the standardized path coefficient was found to be 0.40 and the $\mathrm{t}$-value was found to be (7.03). Hence, our finding supports the view that purposes of Facebook usage has a significant positive effect on the usage of Facebook $(p<.005)$ (H13 supported). Similarly, it was found that users' purposes with their determinants by Facebook purpose account for approximately $65 \%\left(\mathrm{R}^{2}\right)$ of the variance of usage of Facebook. 
Table 3 Model fit indices for the measurement model

\begin{tabular}{|c|c|c|c|}
\hline Index & Perfect fit & Accepted values & Model results \\
\hline$x^{2} / \mathrm{d} f$ & $x^{2} / \mathrm{d} f<3$ & $3<x^{2} / \mathrm{d} f<5$ & 2.77 \\
\hline AGFI & $0.90<$ AGFI $<1$ & $0.85<\mathrm{AGFI}<0.90$ & 0.9 \\
\hline RMSEA & $0<$ RMSEA $<0.05$ & $\begin{array}{l}0.05<\text { RMSEA }< \\
0.08\end{array}$ & 0.065 \\
\hline CFI & $0.97<\mathrm{CFI}<1$ & $0.95<\mathrm{CFI}<0.97$ & 0.97 \\
\hline IFI & $0.95<\mathrm{IFI}<1$ & $0.090<\mathrm{IFI}<0.95$ & 0.97 \\
\hline TLI & $0.90<\mathrm{AGFI}<1$ & $0.90<\mathrm{AGFI}<0.95$ & 0.96 \\
\hline GFI & $0.95<\mathrm{GFI}<1$ & $0.90<\mathrm{GFI}<0.95$ & 0.93 \\
\hline
\end{tabular}

The Cronbach's alpha reliability coefficient of the scale was found to be 0.883 . The Cronbach's alpha values for each of the factors, factor loadings of the items and goodness of fit indexes of confirmatory factor analyze results are presented in the tables (Tables 4, 5 and 6).

\section{Discussion}

While analyzing this study, we have tested a structural equation model using SPSS and AMOS to explain the educational use of Facebook. Taking support of this model we investigated, Usage of Facebook which is examined in five dimensions of Facebook

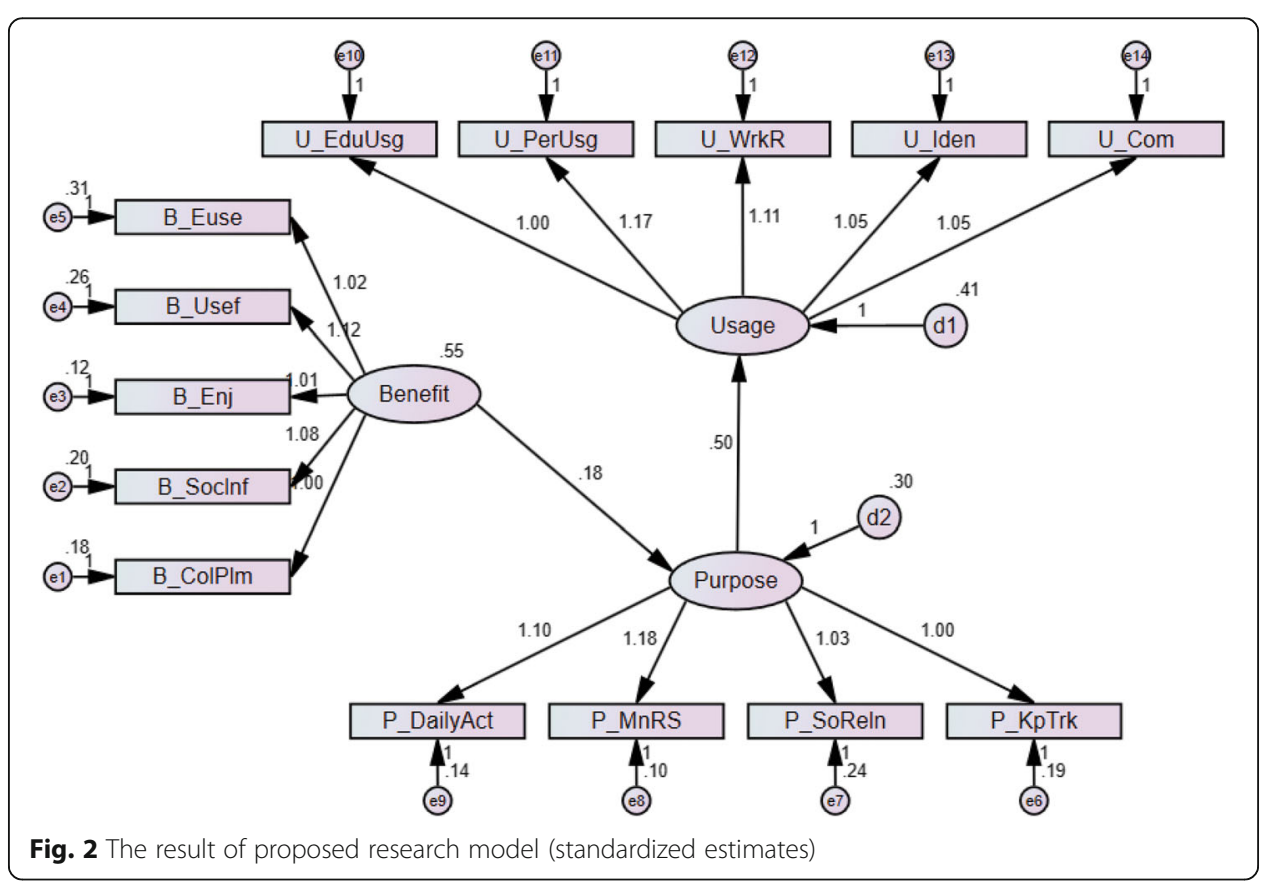






communication including perceived identification, educational use, work related and personal usage. While testing the model, usage of Facebook is explained indirectly by purposes of Facebook and directly by benefit of Facebook. Benefit of Facebook was found to have a significant positive relationship with perceived usefulness, perceived ease of use, social influence perceived enjoyment and collaborative platform. Perceived enjoyment is determined as the most important factor in predicting the Benefit of Facebook. Therefore, enjoyment as perceived by Facebook users can be indicated as one of the major reasons for the expeditious use of Facebook and the expeditious increase in the number of its users.

In this study, we investigated three main factors for their influence on learner's performance to learn English. This study was carried out in Japan where most of the people are shy to speak in English due to less practice in speaking English. Fourteen hypotheses of this study were accepted and this finding is consistent with previous researches. Learners' skills also appeared to be developed through the use of social media in the context of learning English.

The results of the present study also disclosed that users' purposes and informationseeking behaviors in web-based media have a strong and positive correlation with users' social communities, resource and networking information sharing, routine activities and daily task tracking. Our finding is consistent with previously published reports. For example, (Lenhart \& Madden, 2017) reported that 55\% of teenagers use social networking technology and most of users utilize social media social for having fun, meeting new people and making friends, staying in touch with existing friends and posting messages, images and files, etc. In 2008, Joinson described that people use social networking sites to keep in touch with old friends from high school, college, or a past job, reconnect with professional network and lost contacts, communicate with people with similar interests, join social groups for different purposes, organize community-driven awareness events, post and share photos, view and save friends' photographs etc. The 
Table 4 Path coefficients and t-values between observed and latent variables

\begin{tabular}{llcr}
\hline Latent Variables & Observed Variables & Path coefficients & T-value \\
Benefit & B_Euse & 0.80 & 8.287 \\
& B_Usef & 0.85 & 7.173 \\
& B_Enj & 0.90 & 4.830 \\
& B_Soclnf & 0.87 & 5.377 \\
& B_ColPlm & 0.87 & 5.622 \\
\hline Purpose & P_DailyAct & & \\
& P_MnRS & 0.86 & 23.7 \\
& P_SoReln & 0.9 & 23.241 \\
& P_KpTrk & 0.76 & 19.264 \\
Usage & U_EduUsg & 0.79 & 20.506 \\
& U_PerUsg & & \\
& U_WrkR & 0.76 & 9.721 \\
& U_Iden & 0.88 & 10.289 \\
& U_Clb & 0.86 & 11.593 \\
& & 0.89 & 16.934 \\
& & 0.77 & 7.633 \\
\hline
\end{tabular}

results obtained for this study revealed that the consumption of social media (Facebook) for resource and material sharing is one of most vital factor among all of the intensive purposes studied. Our research have showed that social media can be associated with the fact that interactive Facebook mediated social media technology facilitate the virtual sharing of study material, educational resources, ideas, career interests and related information. The overall results indicate that the proper use of Facebook can have various positive effects on communication, perceived identification and emotional reactions, personal and work-related purposes, academic performances, but it all depends on how you user use advanced features of this platform.

Based on our findings, we speculated that consuming Facebook with the motive of maintaining personal and professional social relationships is directly associate with

Table 5 average variance extracted (AVE) and composite reliability (CR) analysis

\begin{tabular}{|c|c|c|c|c|c|c|c|}
\hline & Factors (f) & F2 & E.V & Cronbach's Alpha $\alpha$ & $\begin{array}{l}\text { Average variance } \\
\text { extracted(AVE) }\end{array}$ & $\begin{array}{l}\text { Composit } \\
\text { Realability } \\
\text { (CR) }\end{array}$ & $\mathrm{N}$ \\
\hline B_ColPlm & 0.791 & 0.625 & 0.375 & \multirow{5}{*}{0.932} & \multirow{5}{*}{0.740} & \multirow{5}{*}{0.934} & \multirow{5}{*}{5} \\
\hline B_Soclnf & 0.850 & 0.722 & 0.278 & & & & \\
\hline B_Enj & 0.911 & 0.830 & 0.170 & & & & \\
\hline B_Usef & 0.877 & 0.769 & 0.231 & & & & \\
\hline B_Euse & 0.867 & 0.751 & 0.249 & & & & \\
\hline P_KpTrk & 0.873 & 0.762 & 0.238 & \multirow{5}{*}{0.898} & \multirow{5}{*}{0.658} & \multirow{5}{*}{0.905} & \multirow{5}{*}{5} \\
\hline P_SoReln & 0.953 & 0.908 & 0.092 & & & & \\
\hline P_MnRS & 0.729 & 0.531 & 0.469 & & & & \\
\hline P_DailyAct & 0.736 & 0.542 & 0.458 & & & & \\
\hline U_EduUsg & 0.739 & 0.546 & 0.454 & & & & \\
\hline U_PerUsg & 0.905 & 0.819 & 0.181 & \multirow{4}{*}{0.917} & \multirow{4}{*}{0.730} & \multirow{4}{*}{0.915} & \multirow{4}{*}{4} \\
\hline U_WrkR & 0.827 & 0.684 & 0.316 & & & & \\
\hline U_Iden & 0.886 & 0.785 & 0.215 & & & & \\
\hline U_Com & 0.794 & 0.631 & 0.369 & & & & \\
\hline
\end{tabular}


Table 6 Squared Multiple Correlations $\left(R^{2}\right)$

\section{Estimate}

Usage

0.16

Benefit

0.06

U_Clb

0.60

U_Iden

0.79

U_WrkR

0.74

U_PerUsg

0.78

U_EduUsg

0.58

P_Daily Act

0.73

P_MnRS

0.82

P_SoReln

0.58

P_KpTrk

0.62

B_Euse

0.65

B_Usef

0.72

B_Enj

0.82

B_Soclnf

0.76

B_ColPlm

0.75

utilization for communication purposes. In this study, we observed that most of the Facebook users who participated in research work not only nurtured and balanced their relationships and communication patterns with their classmates and near and dear ones but they also shared ideas and exchanged information and views during overall communication process. Selwyn (2009) also reported that students' use of Facebook in educational contexts could be classified into five different categories; recounting the events of their social media based learning activities and reflecting on their university on the linkages between their university experiences and educational contents, practical information regarding exchanging academic materials and resources, and exchanging potentially humorous ideas or entertaining materials. All of the assumptions support our results, which suggest that use of various Facebook features in daily activities, are strongly related with its educational usage capabilities.

In this study we also found that Facebook usage have a positive relationship with its observed variables and all the observed variables have almost equal distributions, that 
means students are willing to accept Facebook as one of the study tools. This study also shows that user's purpose in using Facebook have a positive relationship with Facebook benefit. That means student's find using Facebook very beneficial and useful for study purposes. The model was stipulated as good or even better on the radiance of the values that we got from the analysis and the 14 hypotheses of the study were verified and accepted. New correlations were also added to the model and the validity of the model was confirmed by the indices and goodness of fit indices. All of these results confirm that social media has many advantages like being useful, ease to use, communicable and can be lot beneficial for learning new things.

\section{Conclusions}

Currently, social media and communication technology have become ubiquitous and is absolutely reshaping almost every facet of human life in an unprecedented manner, and education sector is no exception. Social networking technologies have attracted hundreds of millions of users with different ages, gender, culture, language, educational qualifications or social status to build social networks, communicate and interact with each other for mutual assistance through the past years, which is of paramount importance for identifying the human behavior and relation patterns in different platforms. As one of these social networks, Facebook has diffused rapidly throughout the world because of its popularity and general pervasiveness in everyday life. Facebook has become a significant variable that influence the psychological and social functioning of numerous people, especially youth, from different backgrounds worldwide. Social media growth drifts reflect that more and more students of different age groups and educational levels are catching on and using social networking platforms. In parallel, demands and realistic expectations of school/college or university students in an age of digital social media are enormously changing at a rapid pace.

Although social media technology has the several features for improving the learning process, the use of social networking system has not made significant inroads into classroom or formal educational usage. In this work, we used structural equations modeling to conceptualize the use of Facebook and test a hypothetical model for deep social media analysis. We analysed the influence of various factors and parameters that may have a large effect on student motivation to adopt and use different Web 2.0 tools (Facebook), for various potential educational application. We designed and applied this model to different sample, from different demographic categories (most of the participants were students from the University of Toyama). The main objective of the study was to understand the factors that may attract students to adopt Facebook for education related activities. The comprehensive understanding of these factors can help the social media researchers to identify, develop and apply different strategies for not only increasing the adoption of social media (Facebook) for informal educational activities but to also fully realize the potential benefits of social media for formal learning at numerous educational settings.

Our research on Facebook suggests that social media networks compete with educational work for students' attention. Hence, it is the duty of the student to make the right choice in relation to the use of social media networks for personal or for professional networking in different contexts. We speculate that cultural differences between 
students from different nationalities and their language barriers may greatly influence students' temperament and learning styles, behavioral norms and expectations. Overall, this research work may have several implications for better understanding of students' perceptions towards Facebook. The research work presented in this paper should be of great significance to teachers, researchers, education management and policymakers, social media and Internet regulators, and parents as well.

\section{Additional file}

Additional file 1: Table S1. Pattern Matrix. Table S2. Covariance matrix of latent variables. Table S3.

Standardized Regression Weights. Table S4. Factor Correlation Matrix. Table S5. One-Sample T-test Value. Table

S6. Regression Weights: Hypothesis testing results. Table S7. Factor Score Weights. (DOCX 166 kb)

\section{Authors' contributions}

SA; have conducted the actual study University of Toyama. BAM; collected the data prepared the paper template, HS; advised how to write the paper, and reviewed the paper many times. FAM; reviewed and commented the paper and provided some background information. MS; act as a research advisor and supervised the project progress. All authors read and approved the final manuscript.

\section{Funding}

Not applicable

\section{Availability of data and materials}

The authors of this paper are ready to reproduce the materials and the data including usability test raw data that are presented in the manuscript. The raw data is accessible when scientist or reviewer wishing to use or assess it.

\section{Competing interests}

The authors declare that they have no competing interests.

Received: 12 October 2018 Accepted: 12 June 2019

Published online: 22 July 2019

\section{References}

Ajjan, H., \& Hartshorne, R. (2008). Investigating faculty decisions to adopt Web 2.0 technologies: Theory and empirical tests. Internet and Higher Education, 11(2), 71-80.

Ajzen, I. (1991). The theory of planned behavior. Organizational Behavior and Human Decision Processes, 50(2), $179-211$. Amichai-Hamburger, Y., \& Vinitzky, G. (2010). Social network use and personality. Computers in Human Behavior, 26, 12891295.

Anderson, P., Hepworth, M., Kelly, B., \& Metcalfe, R. (2010). What is Web 2.0? Ideas, technologies and implications for education. Bristol: JISC, 1(1), 1-64.

Apaolaza, V., Hartmann, P., Medina, E., Barrutia, J. M. \& Echebarria, C. (2013). The relationship between socializing on the Spanish online networking site Tuenti and teenagers' subjective wellbeing: The roles of self-esteem and loneliness. Computers in Human Behavior, 29, 1282-1289.

Aydin, S. (2014). Foreign language learners' interactions with their teachers on Facebook. System, 42, 155-163.

Bowers-Campbell, J. (2008). Cyber "pokes": Motivational antidote for developmental college readers. Journal of College Reading \& Learning, 39(1), 74-87.

Brailovskaia, J., \& Bierhoff, H. W. (2016). Cross-cultural narcissism on facebook: Relationship between self-presentation, social interaction and the open and covert narcissism on a social networking site in Germany and Russia. Computers in Human Behavior, 55, 251-257.

Carlile, O., Jordan, A., \& Stack, A. (2004). Learning by design: Learning theory for the designer of multimedia educational materials. Waterford: WIT/BBC.

Chae, J. (2018). Reexamining the relationship between social media and happiness: The effects of various social media platforms on reconceptualized happiness. Telematics and Informatics, 35(6), 1656-1664.

Charlton, P., Magoulas, G., \& Laurillard, D. (2012). Enabling creative learning design through semantic technologies. Technology, Pedagogy and Education, 21(2), 231-253.

Chawinga, W. D., \& Zinn, S. (2016). Use of Web 2.0 by students in the Faculty of Information Science and Communications at Mzuzu University, Malawi. South African Journal of Information Management, 18(1), 1-2.

Cheung, C. M. K., Chiu, P. Y., \& Lee, M. K. O. (2011). Online social networks; Why do students use Facebook? Computers in Human Behavior, 27(4), 1337-1343.

Choi, T. R., \& Sung, Y. (2018). Instagram versus Snapchat: Self-expression and privacy concern on social media. Telematics and Informatics, 35(8), 2289-2298.

Christofides, E., Muise, M., \& Desmarais, S. (2009). Information disclosure and control on Facebook: Are they two sides of the same coin or two different processes? CyberPsychology \& Behavior, 12, 341-345.

Correa, T., Willard Hinsley, A., \& Gil se Zuniga, H. (2010). Who interacts on the web?: The intersection of users' personality and social media use. Computers in Human Behaviour, 26, 247-253.

Corrocher, N. (2011). The adoption of Web 2.0 services: An empirical investigation. Technological Forecasting and Social Change, 78(4), 547-558. 
Curran, J. M., \& Meuter, M. L. (2007). Encouraging existing customers to switch to self-service technologies: Put a little fun in their lives. Journal of Marketing Theory and Practice, 15(4), 29-51.

Dabner, N. (2012). "Breaking ground" in the use of social media: A case study of a university earthquake response to inform educational design with Facebook. Internet and Higher Education, 15(1), 69-78.

Davis, F., Bagozzi, R. \& Warshaw, P. (1992). Extrinsic and Intrinsic Motivation to Use Computers in the Workplace. Journal of Applied Social Psychology, 22, 1111-1132.

Davis, F. D. (1989). Perceived usefulness, perceived ease of use, and user acceptance of information technology. MIS Quarterly, 13(3), 319-340.

Davis, F. D. (1993). User acceptance of information technology: System characteristics, user perceptions and behavioral impacts. International Journal of Man-Machine Studies, 38, 475-487.

Debatin, B., Lovejoy, J., Horn, A., \& Hughes, B. (2009). Facebook and online privacy: Attitudes, behaviors, and unintended consequences. Journal of Computer- Mediated Communication, 15(1), 83-108.

Dholakia U.M., Bagozzi, R., Pearo, L. (2004). A Social Influence Model of Consumer Participation in Network- and Small-GroupBased Virtual Communities. International Journal of Research in Marketing, 21(3), 241-263.

Dickie, V. A., \& Meier, H. (2015). The Facebook tutor: Networking education. Ubiquitous Learning, 8(2), 1-12.

Donlan, L. (2014). Exploring the views of students on the use of Facebook in university teaching and learning. Journal of Further and Higher Education, 38(4), 572-588.

Dzvapatsva, G. P., Mitrovic, Z., \& Dietrich, A. D. (2014). Use of social media platforms for improving academic performance at further education and training colleges. South African Journal of Information Management, 16(1), 1-7.

Eighmey, J., \& McCord, L. (1998). Adding value in the information age: Uses and gratifications of sites on the world wide web. Journal of Business Research, 41(3), 187-194.

Ellison, N. B., Steinfield, C., \& Lampe, C. (2007). The benefits of Facebook "friends": Social capital and college students' use of online social network sites. Journal of Computer- Mediated Communication, 12(4), 1143-1168.

Erdem, M., \& Kibar, P. N. (2014). Students' opinions on facebook supported blended learning environment. The Turkish Online Journal of Educational Technology, 13(1), 199-206.

Eriksson, K., Kerem, K., \& Nilsson, D. (2005). Customer acceptance of internet banking in Estonia. International Journal of Bank Marketing, 23(2), 200-216 https://newsroom.fb.com/company-info/ http://www.bbc.com/future/story/ 20180104-is-social-media-bad-for-you-the-evidence-and-the-unknowns (https:/wearesocial.com/blog/2018/01/globaldigital-report-2018)

Ertmer, P., Newby, J., Liu, W., Tomory, A., Yu, J. H., \& Lee, Y. M. (2011). Students' confidence and perceived value for participating in cross-cultural wiki-based collaborations. Educational Technology Research and Development, 59(2), 213-228.

Fishbein, M., \& Aizen, I. (1975). Belief, attitude, intention and behaviour: An introduction to theory and research. Reading: Addison-Wesley.

Fogel, J., \& Nehmad, E. (2009). Internet social network communities: Risk taking, trust, and privacy concerns. Computers in Human Behavior, 25(1), 53-160

Forkosh-Baruch, A., \& Hershkovitz, A. (2012). A case study of Israeli highereducation institutes sharing scholarly information with the community via social networks. Internet and Higher Education, 15(1), 58-68.

Gikas, J., \& Grant, M. M. (2013). Mobile computing devices in higher education: Student perspectives on learning with cellphones, smartphones \& social media. The Internet and Higher Education, 19, 18-26.

Greenhow, C., Robelia, B., \& Hughes, J. E. (2009). Learning, teaching, and scholarship in a digital age: Web 2.0 and classroom research: What path should we take now? Educational Researcher, 38(4), 246-259.

Guriting, P., \& Ndubisi, N. O. (2006). Borneo online banking: Evaluating customer perceptions and behavioural intention. Management Research News, 29(1/2), 6-15.

Hamid, S., Waycott, J., Kurnia, S., \& Chang, S. (2015). Understanding students' perceptions of the benefits of online social networking use for teaching and learning. The Internet and Higher Education, 26, 1-9.

Hansen, D., Shneiderman, B., \& Smith, M. A. (2010). Analyzing social media networks with NodeXL: Insights from a connected world. Elsevier/Morgan Kaufmann.

Hair, J. F., Black, W. C., Babin, B. J., \& Anderson, R. E. (2010). Multivariate data analysis (7th ed.). Englewood Cliffs: Prentice Hall, USA.

Hargittai, E. (2007). Whose space? Differences among users and non-users of social network sites. Journal of ComputerMediated Communication, 13(1), 276-297.

Hayes, M., van Stolk-Cooke, K., \& Muench, F. (2015). Understanding Facebook use and the psychological affects of use across generations. Computers in Human Behavior, 49, 507-511.

Hogg, M. A. (2012). Uncertainty-identity theory. In P. A. M. van Lange, A. W. Kruglanski, \& E. T. Higgins (Eds.), Handbook of theories of social psychology (pp. 62-80). Thousand Oaks: SAGE.

Inma, R. A., \& Antoni, M. A. (2018). The playfulness of Facebook - Shaped by underlying psychological drivers and gender differences. Telematics and Informatics, 35(8), 2254-2269.

Ito, M., Horst, H., Bittanti, M., Boyd, D., Herr-Stephenson, R., Lange, P., et al. (2008). Living and learning with new media. Chicago: MacArthur Foundation.

Jones, A. (2015). How twitter saved my literature class: A case study with discussion. In C. Wankel, M. Marovich, K. Miller, \& J. Stanaityte (Eds.), Teaching arts and science with the new social media, (pp. 91-105). Bingley: Emerald Group Publishing.

Joseph, F. H., Marko, S., Torsten, M. P., \& Christian, M. R. (2012). The use of partial least squares structural equation modeling in strategic management research: A review of past practices and recommendations for future applications. Long Range Planning, 45(5-6), 320-340.

Junco, R. (2015). Student class standing, Facebook use, and academic performance. Journal of Applied Developmental Psychology, 36, 18-29.

Junior, M. P., Xavier, S. I. D. R., \& Prates, R. O. (2014). Investigating the use of a simulator to support users in anticipating impact of privacy settings in facebook. In Proceedings of the 18th international conference on supporting group work, (pp. 63-72). ACM, USA.

Kirschner, P. A., \& Karpinski, A. C. (2010). Facebook ${ }^{\circledR}$ and academic performance. Computers in Human Behavior, 26(6), 1237-1245.

Kross, E., Verduyn, P., Demiralp, E., Park, J., Lee, D. S., Lin, N., \& Ybarra, O. (2013). Facebook use predicts declines in subjective well-being in young adults. PLoS One, 8, e69841. 
Külcü, Ö., \& Henkoğlu, T. (2014). Privacy in social networks: An analysis of facebook. International Journal of Information Management, 34(6), 761-769.

Kuzma, J. M., \& Wright, W. (2013). Using social networks as a catalyst for change in global higher education marketing and recruiting. International Journal of Continuing Engineering Education and Life-Long Learning, 23(1), 53-66.

Lai, H.-M., \& Chen, C.-P. (2011). Factors influencing secondary school teachers' adoption of teaching blogs. Computers \& Education, 56(4), 948-960.

Larusson, J., \& Alterman, R. (2009). Wikis to support the collaborative part of collaborative learning. International Journal of Computer-Supported Collaborative Learning, 4, 76.

Lee, E. B. (2011). Young, black, and connected: Facebook usage among African American college students. Journal of Black Studies. https://doi.org/10.1177/0021934711425044.

Lee, M.J.W., \& McLoughlin, C. (2008). Harnessing the affordances of Web 2.0 and social software tools: Can we finally make "student-centered" learning a reality? In Proceedings of World Conference on Educational Multimedia, Hypermedia and Telecommunications, (pp 3825-3834), ED-MEDIA, Austria.

Lenhart and Madden (2007). https://www.pewinternet.org/2007/01/07/social-networking-websites-and-teens/.

Liao, Z., \& Cheung, M. T. (2002). Internet-based e-banking and consumer attitudes: An empirical study. Information \& Management, 39(4), 283-295.

Livingstone, S. (2009). Children and the internet: Great expectations and challenging realities. Cambridge: Polity.

Lönnqvist, J. E., \& große Deters, F. (2016). Facebook friends, subjective well-being, social support, and personality. Computers in Human Behavior, 55, 113-120.

Madge, C., Meek, J., Wellens, J., \& Hooley, T. (2009). Facebook, social integration and informal learning at university: "It is more for socialising and talking to friends about work than for actually doing work". Learning, Media \& Technology, 34(2), 141-155.

Maloney, E. (2007). What Web 2.0 can teach us about learning. The Chronicle of Higher Education, 53(18), B26.

Mao, J. (2014). Social media for learning: A mixed methods study on high school students' technology affordances and perspectives. Computers in Human Behavior, 33, 213-223.

Mason, R. (2006). Learning technologies for adult continuing education. Studies in Continuing Education, 28(2), 121-133.

Mazer, J. P., Murphy, R. E., \& Simonds, C. J. (2007). I'll see you on Facebook: The effects of computer-mediated teacher selfdisclosure on student motivation, affective learning, and classroom climate. Communication Education, 56(1), 1-17.

Mazman, S. G., \& Usluel, Y. K. (2010). Modeling educational use of Facebook. Computers \& Education, 55(2), 444-453.

Meishar-Tal, H., Kurtz, G., \& Pieterse, E. (2012). Facebook groups as LMS: A case study. The International Review of Research in Open and Distance Learning, 13(4), 33-48.

Mendes, M. S., Furtado, E., Militao, G., \& de Castro, M. F. (2015). Hey, I have a problem in the system who can help me an investigation of facebook users interaction when facing privacy problems. In International conference on human aspects of information security, privacy, and trust, (pp. 391-403).

Milosevic, l., Zivkovic, D., Arsic, S., \& Manasijevic, D. (2015). Facebook as virtual classroomeSocial networking in learning and teaching among Serbian students. Telematics and Informatics, 32(4), 576-585.

Moore, G. C., \& Benbasat, I. (1991). Development of an instrument to measure the perceptions of adopting an information technology innovation. Information Systems Research, 2(3), 192-222.

Moretta, T., \& Buodo, G. (2019). Modeling problematic Facebook use: Highlighting the role of mood regulation and preference for online social interaction. Addictive Behaviors, 88, 214-221.

Oh, H. J., Ozkaya, E., \& LaRose, R. (2014). How does online social networking enhance life satisfaction? The relationships among online supportive interaction, affect, perceived social support, sense of community, and life satisfaction. Computers in Human Behavior, 30, 69-78.

Patterson, A. (2012). Social-networkers of the world, unite and take over: A meta-introspective perspective on the Facebook brand. Journal of Business Research, 65(4), 527-534.

Pempek, T. A., Yevdokiya, A. Y., \& Calvert, S. L. (2009). College students networking experiences on Facebook. Journal of Applied Developmental Psychology, 30(3), 227-238.

Pentland A, Reinventing society in the wake of big data, Edge.org, 2016. Available: https://www.edge.org/conversation/alex sandy_pentland-reinventing-society-in-the-wake-of-big-data.

Prescott, J., Wilson, S., \& Becket, G. (2013). Facebook use in the learning environment: Do students want this? Learning, Media and Technology, 38(3), 345-350

Qureshi, I. A., Raza, H., \& Whitty, M. (2015). Facebook as e-learning tool for higher education institutes. Knowledge Management \& E-Learning: An International Journal (KM\&EL), 6(4), 440-448,

Riedlinger, M.E., Gallois, C., McKay, S., \& Pittam. (2004). Impact of Social Group Processes and Functional Diversity on Communication in Networked Organizations. Journal of Applied Communication Research, 32(1), 55-79.

Roblyer, M. D., McDaniel, M., Webb, M., Herman, J., \& Witty, J. V. (2010). Findings on Facebook in higher education: A comparison of college faculty and student uses and perceptions of social networking sites. Internet and Higher Education, 13(3), 134-140.

Rodriguez, C. O., \& Keane, M. T. (2018). Attention to news and its dissemination on twitter: A survey. Computer Science Review, 29, 74-94.

Rogers, E. (2003). Diffusion of innovations. New York: Free Press.

Ross, C., Orr, E. S., Sisic, M., Arseneault, J. M., Simmering, M. G., \& Orr, R. R. (2009). Personality and motivations associated with Facebook use. Computers in Human Behavior, 25(2), 578-586.

Ryan, T., \& Xenos, S. (2011). Who use Facebook? An investigation into the relationship between the "big five", shyness, narcissism, loneliness, and Facebook usage. Computers in Human Behaviour, 27(5), 1658-1664.

Saeri, A. K., Ogilvie, C., La Macchia, S. T., Smith, J. R., \& Louis, W. R. (2014). Predicting facebook users' online privacy protection: Risk, trust, norm focus theory, and the theory of planned behavior. The Journal of Social Psychology, 154(4), 352-369.

Sagioglou, C., \& Greitemeyer, T. (2014). Facebook's emotional consequences: Why facebook causes a decrease in mood and why people still use it. Computers in Human Behavior, 35, 359-363.

Sanchez, R. A., Cortijo, V., \& Javed, U. (2014). Students perceptions of Facebook for academic purposes. Computers \& Education, 70(1), 138-149. 
Schroeder, J., \& Greenbowe, T. (2009). The chemistry of Facebook: Using social networking to create an online community for the organic chemistry. Innovate: Journal of Online Education, 5(4), 167-176.

Scolari, C. A. (Ed.) (2018). Teens, media and collaborative cultures. Exploiting teens' transmedia skills in the classroom. Barcelona: Transliteracy H2020 Research Project.

Scolari, C. A., Masanet, M.-J., Guerrero-Pico, M., \& Establés, M.-J. (2018). Transmedia literacy in the new media ecology. An international map of Teens' transmedia skills and informal learning strategies. The Information Professional, 27(4), 801-812.

Selwyn, N. (2009). Faceworking: Exploring students' education-related use of Facebook. Learning, Media and Technology, 34(2), $157-174$.

Sharma, S. K., Joshi, A., \& Sharma, H. (2016). A multi-analytical approach to predict the Facebook usage in higher education. Computers in Human Behaviour, 55, 340-353.

Shen, J., Brdiczka, O., \& Liu, J. (2015). A study of facebook behavior: What does it tell about your neuroticism and extraversion? Computers in Human Behavior, 45, 32-38.

Sobaih, A. E. E., Moustafa, M. A., Ghandforoush, P., \& Khan, M. (2016). To use or not to use? Social media in higher education in developing countries. Computers in Human Behavior, 58, 296-305.

Stutzman, F. (2006). Our lives, our facebooks. In Paper presented at the 26th INSNA conference, in Vancouver, Canada.

Thompson, P. (2013). The digital natives as learners: Technology use patterns and approaches to learning. Computers \& Education, 65(1), 12-33.

Thompson, S. H., \& Lougheed, E. (2012). Frazzled by Facebook? An exploratory study of gender differences in social network communication among undergraduate men and women. College Student Journal, 46(1), 88-99.

Toker, S., \& Baturay, M. H. (2019). What foresees college students' tendency to use facebook for diverse educational purposes? International Journal of Educational Technology in Higher Education, 16, 9.

Towner, T., \& Munoz, C. (2011). Facebook and education: A classroom connection. In Educating educators with social media: Cutting edge technologies in higher education, (vol. 1, pp. 33-57).

Triandis, H. C. (1980). Values, attitudes, and interpersonal behavior. In H. Howe, \& M. Page (Eds.), Nebraska symposium on motivation, (vol. 27, pp. 195-259). Lincoln: University of Nebraska Press.

Tsay-Vogel, M., Shanahan, J., \& Signorielli, N. (2016). Social media cultivating perceptions of privacy: A 5-year analysis of privacy attitudes and self-disclosure behaviors among facebook users. 20 (1), 141-161. New Media \& Society.

Urista, M. A., Dong, Q., \& Day, K. D. (2009). Explaining why young adults use MySpace and Facebook through uses and gratifications theory. Human Communication, 12(2), 215-229.

Valkenburg, P. M., Koutamanis, M., \& Vossen, H. G. (2017). The concurrent and longitudinal relationships between adolescents' use of social network sites and their social self-esteem. Computers in Human Behavior, 76, 35-41.

Veletsianos, G., \& Navarrete, C. (2012). Online social networks as formal learning environments: Learner experiences and activities. International Review of Research in Open and Distance Learning, 13(1), 144-166.

Venkatesh, V., \& Davis, F. D. (2000). A theoretical extension of the technology acceptance model: Four longitudinal field studies. Management Science, 46(2), 186-204.

Venkatesh, V., Morris, M. G., Davis, G. B., \& Davis, F. D. (2003). User acceptance of information technology: Toward a unified view. MIS Quarterly, 27(3), 425-478.

Wandeep, K., Vimala, B., Omer, R., \& Ajantha, S. (2019). Liking, sharing, commenting and reacting on Facebook: User behaviors' impact on sentiment intensity. Telematics and Informatics, 39, 25-36.

Wilson, K., Fornasier, S., \& White, K. M. (2010). Psychological predictors of young adults' use of social networking sites. Cyberpsychology, Behaviour and Social Networking, 13(2), 173-177.

Yunus, M. M., \& Salehi, H. (2012). The effectiveness of Facebook groups on teaching and improving writing: Students' perceptions. Journal of Education and Information Technologies, 1(6), 87-96.

Zhao, S., Grasmuck, S., \& Martin, J. (2008). Identity construction on Facebook: Digital empowerment in anchored relationships. Computers in Human Behavior, 24(5), 1816-1836.

\section{Publisher's Note}

Springer Nature remains neutral with regard to jurisdictional claims in published maps and institutional affiliations.

\section{Submit your manuscript to a SpringerOpen ${ }^{\circ}$ journal and benefit from:}

- Convenient online submission

- Rigorous peer review

- Open access: articles freely available online

- High visibility within the field

- Retaining the copyright to your article

Submit your next manuscript at $\boldsymbol{\Delta}$ springeropen.com 